\title{
Comparative oncology: Integrating human and veterinary medicine
}

\author{
Faheem Sultan ${ }^{1, *}$ and Bilal Ahmad Ganaie ${ }^{2}$ \\ ${ }^{1}$ Indian Council of Medical Research, GADVASU-Ludhiana Punjab-141004, India \\ ${ }^{2}$ National Dairy Research Institute, Karnal Haryana-132001, India
}

\begin{abstract}
Cancer constitutes the major health problem both in human and veterinary medicine. Comparative oncology as an integrative approach offers to learn more about naturally occurring cancers across different species. Canine models have many advantages as they experience spontaneous disease, have many genes similar to human genes, five to seven-fold accelerated ageing compared to humans, respond to treatments similarly as humans do and health care levels second only to humans. Also, the clinical trials in canines could generate more robust data, as their spontaneous nature mimics real-life situations and could be translated to humans.
\end{abstract}

Keywords: Canine, Human, Oncology.

\section{Introduction}

It has been an aspiration of scientific research to comprehend cancer so to reach a better diagnosis, prevention, and treatment. The exchange of knowledge and practices between human and animal researchers is becoming more common and fruitful. This comparative approach has a promising role in clinicopathological and therapeutic studies. Comparative oncology helps us to study disease pattern, inheritance, genetic history and correlation of a disease between two or more than two distinct species. It integrates the naturally occurring cancers in veterinary patients with more general studies of cancer biology and therapy in humans. Malignant disorders constitute major health problem both in human and veterinary medicine (Singer et al., 2014). Various historical studies suggest that the canine tumours could be informative in studying human cancers (Davis and Ostrander, 2014). However, the comparative approach of treating human and animal patients is a novice concept which has been initiated recently (Paoloni and Khanna, 2008; Gordon et al., 2009). Although, the world is witnessing awareness in comparative oncology but the knowledge is not translated among cancer researchers. India is still far behind in such studies. In order to uptake such a study, collaborations across fields of veterinary and human medicine must be encouraged.

Animal models and cancer research

Animals as biological models have played a very basic role in explicating the physiological and biochemical processes involved in onset, promotion and progression of cancer. Obviously, because of the practical and ethical issues with human experimentation, animals are essential in cancer research. In vitro (test tube and cell culture) and in vivo (animals) studies are required to determine the justification for drug development. Prior animal testing is required by the Food and Drug Administration (FDA) before a new molecular entity is tested in humans. The final aim of the cancer researchers is to translate their findings into practical applications. Experimentally, tumours are raised in laboratory animals like rodents which facilitate newer insights into diagnostic and therapeutic arena (Mak et $a l ., 2014)$. Presently animals are used worldwide to test the safety, toxicity and therapeutic potential of drugs (Cook et al., 2012). Despite the importance of animal models, there are molecular and physiological limitations which question their utility. A large proportion of clinical trials for new drugs fail and the majority of such trials are for cancer drugs (Arrowsmith, 2011; Ledford, 2011). These failures generally occur because of the molecular mechanisms of the drugs involved, unaccepted toxicity or poor efficacy (Simon, 2008). The limitations in animal research are becoming more evident as the laboratory animal models fail to make reliable predictions about human clinical trials (Perel et al., 2007). Such studies generally overestimate the effectiveness of the treatment as the negative results are usually not published (Sena et al., 2010). Also, much of the data obtained from mouse or other laboratory animal models is not reproducible in human clinical conditions (Marchetti and Schellens, 2007). Although the in vitro models have helped us to understand molecular pathways of cancer, they don't model adequately the spontaneous human tumours because of limitations like selective transformation with a selection of certain gene sets, morphologic characters, and functions (MacLeod et al., 1999; Masters, 2002). The mouse has been the most frequent model for genetic studies in mammals

*Corresponding Author: Faheem Sultan. Indian Council of Medical Research, GADVASU-Ludhiana Punjab-141004, 
with advantages like small size, average lifespan of about 2 years, short gestation period and inexpensiveness in contrast to other mammals but it has got significant limitations when used to study complex human diseases (Paigen, 1995; Strauch et al., 2003; Gondo et al., 2009; Seok et al., 2013). There are genetic, immunological and cellular differences between human and mice which make it a poor model for cancer study (Schuh, 2004). Many spontaneous diseases in humans must be induced in laboratory mice but it is very difficult to study polygenetic conditions and interactions between multiple genes (Karlsson and Lindblad, 2008). Certain features of human cancer like long latency periods, heterogeneous macro- and microenvironment and genetic instability cannot be modelled in mouse. Also, metastasis and recurrence cannot be easily explained in this conventional model of cancer. Furthermore, the induced cancers in mice mostly have active telomerase (Kim et al., 1994; Prowse and Greider, 1995), have altered pathways and the mice can tolerate higher levels of drug concentrations with less sensitive bone marrow than human patients (Teicher, 2009). Other limitations like laboratory settings, use of inbred strains and using artificial disease in an otherwise normal animal can have profound effects on the experimental results (Chesler et al., 2002; Karlsson and Lindblad, 2008). In addition, genetic modifications in transgenic mice and different environments produced by the xenografts can increase the differences apart from the evolutionary remoteness between human and mice (Hovey et al., 1999; Balkwill et al., 2005; Goswami et al., 2005; Schwertfeger et al., 2006).

\section{Advantages of spontaneous canine tumours}

When a model is similar to human beings and has the ability to mimic the human pathological conditions, it becomes a good option to utilise this model. Cancer is a complex disease which develops naturally in canines (Starkey et al., 2005). It is the leading cause of death in canines of greater than 10 years of age (Adams et al., 2010; Gardner et al., 2016). Human cancers such as lymphoma, mammary carcinoma, osteosarcoma, soft tissue sarcomas are also diagnosed and reported in dogs (Khanna et al., 2006; Merlo et al., 2008). Similar clinical parameters like organ function tests, cardiac changes, blood pressure can be taken in dogs as in humans. Dog and human have comparable drug metabolic processes and the hepatic enzyme homology of dogs is more similar to humans than to rodents, thus the canine model is considerably suitable for toxicological studies (Smith et al., 2002). There are striking similarities between dog and human diseases like cancer, cardiac disorders, eye diseases, epilepsy, deafness and disorders like obsessive-compulsive disorder (Loscher et al., 1985; Overall, 2000; Vail and MacEwen, 2000; Khanna et al., 2006; Gershwin, 2007). Canines suffer spontaneously from tumors which mirror the characteristics like histopathology, clinical manifestation, metastasis, recurrence, genetic predisposition and patterns of response or resistance to treatment similar to those found in human beings (McEwen, 1990; Hahn et al., 1994; Vail and McEwen, 2000; Paoloni and Khanna, 2008; Schiffman and Breen, 2015). Since the nature of the disease is spontaneous, the complex tissue interactions can be studied which is otherwise difficult to study in other animal model systems. Ethical concerns, as seen with induced cancer models, are not involved while treating canines with naturally occurring cancers.

In veterinary practice, short-term sedation or anaesthesia is commonly used for physical checkups and diagnostic purposes. It makes canines suitable for serial biopsies in comparative oncology trials and thus can help to understand cancer biology and validate the tumour biomarkers which can be correlated with response in ways that are usually not feasible in classical preclinical rodent studies or in human cancer trials. Dogs have a short lifespan and depending upon the breed, the ageing process is five to sevenfold in comparison to human beings (Priester, 1977). This helps to study the clinical condition over a shorter period of time resulting in the earlier assessment of drug activity and toxicity which are critical for future clinical trials in veterinary and human medicine. Also, the companion dogs remain with their owners until their old age (Cummings et al., 1996; Bonnett and Egenvall, 2010). Thus the use of canine population gives doctors and researchers a better resource for understanding the therapeutic outcomes in patients who live in our houses, experience same environment and sometimes eat what we eat. They could even serve as sentinels to detect carcinogenic substances in our homes and surroundings. The completion of the canine genome project and the evolution of newer technologies have expanded the scope of comparative oncology. Looking into the canine genome it seems that approximately 19,000 genes match to similar or orthologous genes in the human genome (Lindblad-Toh et al., 2005; Parker et al., 2006). The canine genome shows higher homology and close similarity with human genome in comparison to rodent genome which highlights the relevance of canine models in comparative oncology.

\section{Challenges in the path of comparative oncology}

Under Indian conditions, the human cancer research organisations are usually not interested in comparative canine oncology studies and the funding opportunities are almost trivial/ negligible. The pet owners have a feeble understanding of the crucial role of preclinical animal models and the opportunity of their companion animals to take part in inter-species clinical discoveries. The understanding of genetic changes/mechanisms which result in human cancers is far higher than those 
which cause canine cancers. This lack of genetic knowledge of canine cancer is a major gap in comparative oncology and translational drug development (LeBlanc et al., 2016). The veterinary academic centres generally lack imaging modalities such as computed tomography (CT), magnetic resonance imaging (MRI), and positron-emission tomography (PET) which would otherwise be helpful in comparative oncology. In human medicine, there are various registries which collect information on incidence, prevalence, risk factors, and survival over space and time. While in human medicine the cancer registries evolved since 1940s, veterinary cancer registries were established from 1961 (Stratus et al., 1976) and existed in small numbers, sporadic in nature and some became nonfunctional. European and American countries have cancer registries for humans and companion animals in order to document all reported cases of cancer. In India, there is no veterinary cancer registry at present compared to many in human oncology. For example, Indian Council of Medical Research has cancer registries which assemble statistics relating to cancer mortality and trends for the whole country. However, nothing like this exists in veterinary science.

\section{Recommendations for a successful outcome}

Veterinary colleges constitute the best option to select and manage canine patients for translational studies and can help in better understanding of cancer biology, assessment of novel treatments, devices, and imaging techniques by involving companion animals with naturally developed cancers. Academic institutions, veterinarians and doctors in the clinical practice and industrial research must be included in the translational research and development. Veterinary cancer registry can be a strong advocate for companion animals as natural models for oncological studies. These registries could help to connect oncologists and researchers with common interests and to educate pet owners about the ongoing clinical trials. A centralised clinical trial registry would help owners and veterinarians to start trials for pets suffering from cancer. However, the affirmation of animal welfare is critical for the success of such a process.

There should be something similar to The Cancer Genome Atlas project (TCGA) in canines in order to address the genetic gap in comparative oncology and to provide high quality readily available data (LeBlanc et al., 2016). Attempts should be made to provide facilities for tumour banks which preserve tumour tissues and other biospecimens. Such banks have a high potential for supporting translational research. Diagnostic modalities like MRI, PET, and CT should be introduced in veterinary practice in order to fill up the technology gap. With the utilisation of new tools and techniques, the possibilities of comparative and translational applications will become a reality. Canines can benefit from the new discoveries made in human oncology and human research can, in turn, get inputs through canine cancer models from pre-clinical studies (Fowles, 2017).

\section{Integrating veterinary and human clinical trials}

Clinical trials in companion animals are not hindered by traditional Phase-I, Phase-II and Phase-III trial designs (Gordon et al., 2009) which allows pet owners to seek novel therapeutics for their pet if the conventional treatments do not meet their goals. Veterinary clinical trials have the potential to be integrated with human clinical trials in a comparative approach which can improve the drug development cycle (Fig. 1). Adding comparative oncology studies in pre-clinical settings can help to identify and cull the unfavourable and inferior drugs or drug targets at an early stage. This will help to identify those drugs or drug targets that are most likely to be working. It can also provide information about the pharmacokinetics and pharmacodynamics of the candidate drug before it enters the actual human trials. Table 1 contains some examples of spontaneous canine cancers which can be used as models for corresponding human cancers and have been used or have the potential to be utilised in anticancer drug developmental process. Using pet dogs can drastically reduce the number of human participants entering in Phase-I, II and III trials. This can increase the success rate in Phase III trials and drastically reduce the costs and potential risks in drug development.

\section{Shared cancers between humans and dogs}

Osteogenic sarcoma or osteosarcoma is an aggressive malignant neoplasm of bone. It shows the highest prevalence in teenagers and young adults (Mirabello et al., 2009). Similar to humans, osteosarcoma (OSA) is the most common bone tumour diagnosed in dogs and typically affects the middle-aged group. Dog breeds that are at higher risk of developing OSA include Rottweiler, Great Pyrenees, Mastiff, Dobermann Pinscher, Irish wolfhound, and Scottish deerhound (Schiffman and Breen, 2015). However, the incidence in dogs is 10-fold greater in comparison to humans $(\mathrm{Ru}$ et al., 1998). As OSA is rare in human population it poses a major challenge to the progress of human clinical trials. However, the higher number of osteosarcomas diagnosed in canine population and the interest of pet owners to take part in clinical trials gives an immense opportunity to the advancement of studies for this condition in both species. Humans develop OSA at similar sites as in dogs and have similar histology and response to therapeutics (Withrow and Wilkins, 2010). Thus, a dog can act as a good model for human OSA. Dogs have been used in clinical trials for developing limb salvage techniques that are presently used in human (LaRue et al., 1989). 


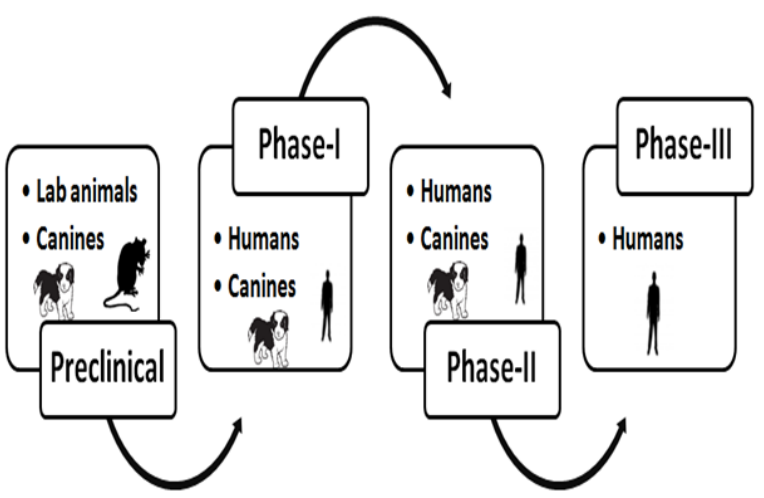

Fig. 1. Integration of veterinary and human clinical trials in drug development process.

Table 1. Spontaneous canine tumours that can model for human cancers and play a role in drug development.

\begin{tabular}{|c|c|}
\hline Tumor & Role in drug development \\
\hline Osteosarcoma & $\begin{array}{l}\text { Limb salvage techniques (LaRue et } \\
\text { al., 1989) } \\
\text { Rapamycin (Paoloni et al., 2010) } \\
\text { Liposome-encapsulated cisplatin } \\
\text { (SPI-77) (Vail et al., 2002) } \\
\text { Tyrosine kinase inhibitor (London et } \\
\text { al., 2003) }\end{array}$ \\
\hline Bladder cancer & $\begin{array}{l}\text { Carboplatin (Chun et al., 1997) } \\
\text { Piroxicam (Knapp et al., 1992) }\end{array}$ \\
\hline Breast cancer & $\begin{array}{l}\text { BCG combined with surgery (Parodi } \\
\text { et al., 1983) } \\
\text { Immunotherapy (Teske et al., 1998) }\end{array}$ \\
\hline $\begin{array}{l}\text { Non-Hodgkin's } \\
\text { lymphoma }\end{array}$ & $\begin{array}{l}\text { Liposomal L-asparaginase (MacEwen } \\
\text { et al., 1992) } \\
\text { Antiangiogenic thrombospondin-I } \\
\text { peptide (ABT526) (Rusk et al., 2006) }\end{array}$ \\
\hline $\begin{array}{l}\text { Soft tissue } \\
\text { sarcoma }\end{array}$ & $\begin{array}{l}\text { Antiangiogenic thrombospondin-I } \\
\text { mimetic peptides (Sahora et al., 2012) } \\
\text { Hyperthermia combined with } \\
\text { irradiation (Gillette } \text { et al., 1992) }\end{array}$ \\
\hline
\end{tabular}

Apart from these, canine osteosarcomas show overexpression of IL- 8 and SLC1A3 which are related to poor outcome of human osteosarcoma (Paoloni et al., 2009). In a comparative study new genes (CDC5L, MYC, RUNX2 and CDKN2A/CDKN2B), that had not been described previously, were revealed in addition to genes (ADAM15, CTC1, MEN1, CDK7) with the known association in osteosarcoma (Angstadt et al., 2012).

Altered signalling pathways involving Wnt, cytokine, apoptosis signalling, interleukin, and Ras were reported in both canine and human OSA (Selvarajah et al., 2009). Thus, studying canine osteosarcoma and the application of new techniques will help reveal the misexpression of other genes involved in human osteosarcoma.

Bladder cancer, also known as transitional cell carcinoma (TCC) or urothelial carcinoma (UC) and affects both canines and humans (Higuchi et al., 2013; Park and Hahn, 2014). TCC comprises about $2 \%$ of all malignant tumours in dogs (Meuten and Mueten, 2014). Canine TCC closely mimics the human invasive bladder cancer in various features like the microscopic features, biological behaviour and response to treatment (Knapp et al., 2000).

Canine and human bladder cancers have been found very similar at the level of transcriptome alterations (Ramsey et al., 2017). Cyclooxygenase-2 (Cox-2) has been found to be overexpressed in both human and canine bladder cancer (Mohammed 1999, Shirahama 2000; Cekanova et al., 2013). Cox inhibitors used in canine bladder cancer treatment have resulted in studies involving human bladder cancer (Knapp et al., 2014). $90 \%$ of human bladder cancers show telomerase activity (Chen and Chen 2011; Eissa et al., 2013). Similarly, such activity has been reported in canine TCC cell lines and clinical cases (McCleary, 2010). Hematuria and changes in urinary habits are common clinical signs in both the species. Bladder cancer is generally diagnosed in older people and dogs. The median age at diagnosis in dogs is about 11 years while as in humans it ranges from the early 60s to 70s (Knapp et al., 2014). These values are almost equivalent on conversion scale of ages between dogs and humans (Patronek et al., 1997)

The mammary tumour is the leading cause of cancer deaths in women followed by lung cancer (Jemal et al., 2011). In canines, mammary gland tumours are second most frequent neoplasms after skin tumours which account for greater than $50 \%$ of the diagnosed tumours (Chang and Elledge, 2001; Sorenmo et al., 2003). The annual incidence rate of mammary cancers in both species is comparable.

The average onset age of mammary tumours in humans is after 40 years (Lilienfeld, 1963) and in dogs, it is after 6-7 years (Cohen et al., 1974). These ages are almost same on the comparative scale (Patronek et al., 1997). Literature reveals many similarities between mammary tumours of both the species. The role of hormonal influence in breast cancer carcinogenesis has been recognised both in canines (Donnay et al., 1995) and humans (Bernstein, 2002).

At the molecular level, there is overexpression of steroid hormone receptors like oestrogen (ER) and progesterone (PR) (MacEwen et al., 1982; Rutteman et al., 1988). The degree of tumoral differentiation is related to the presence of ER (Block et al., 1975; MacEwen et al., 1982). Transformation-related protein-53 (TRP53) gene plays a crucial role in preventing cancer occurrence and is the most frequently altered gene in human cancer (Surget et al., 2013). In mammary tumours in both species, the frequency of P53 mutation is same (20\%) (Lee et al., 2004; Kim et al., 2010). 
Canine simple carcinomas histologically mimic typical human breast carcinomas and could serve as a cancer model for basal-like tumours (Liu et al., 2014). These features support the use of canine mammary tumours as a spontaneous tumour model with diverse translational value to human mammary carcinogenesis.

Lymphomas are cancers of the lymphatic system and affect lymphocytes. Lymphomas are of two types Hodgkin's lymphoma and non-Hodgkin's lymphoma (NHL). The incidence of lymphoma is almost similar in humans and dogs (15.5-29 vs 15-30 per lakh, respectively) (Vail and MacEwen, 2000; Hansen and Khanna, 2004). Lymphoma of B-cells is the most common type of NHL in humans and dogs (Hansen and Khanna, 2004). There is a similarity in tumour behaviour and genetic alterations between dogs and humans, suggesting common pathways or pathological basis of lymphoma (Breen and Modiano, 2008) and allows the use of WHO criteria for the better classification of canine tumours (Vezzali et al., 2010). Thus, there is a great scope for using dogs with lymphoma in the evaluation of therapeutics for both human and veterinary purposes.

Soft tissue sarcomas (STS) like angiosarcoma, liposarcoma, fibrosarcoma, epithelioid sarcoma, histiosarcoma are genetically complex cancers which show high variability in their clinical picture and cellular morphology. These cancers are usually uncommon and account for less than $1 \%$ of newly diagnosed cancers in humans (Krikelis and Judson, 2010). In order to study STS in rodent models experimental induction is generally needed but in contrast, the dog represents an excellent model for such cancer because of spontaneous occurrence and similar genetic complexity (Aguirre-Hernandez et al., 2009). Numerous similarities, like the histological classification and pathogenesis, between canine and human rhabdomyosarcoma, have been reviewed (Caserto, 2013). Thus, the canine model has a clear edge over other models for studying human STS.

\section{Conclusion}

Considering the failures in cancer drug development and the complexity of cancer biology, the laboratory models of cancer suffer from some serious limitations. Pet dogs can be utilised as a unique model of cancer owing to their genetic relatedness to humans besides spontaneous occurrence of cancer. Utilisation of canine models, however, requires collaboration across different fields of human and veterinary medicine like genetics, molecular biology, pharmacology, epidemiology, and a series of other disciplines. This integrative and comparative study could promote research leading to novel treatments and improved health care for humans and their companion animals.

\section{Conflict of interest}

The authors declare that there is no conflict of interests.

\section{References}

Adams, V.J., Evans, K.M., Sampson, J. and Wood, J.L.N. 2010. Methods and mortality results of a health survey of purebred dogs in the UK. J. Small Anim. Pract. 51, 512-524.

Aguirre-Hernandez, J., Milne, B.S., Queen, C., O'Brien, P.C., Hoather, T., Haugland, S., FergusonSmith, M.A., Dobson, J.M. and Sargan, D.R. 2009. Disruption of chromosome 11 in canine fibrosarcomas highlights an unusual variability of CDKN2B in dogs. BMC Vet. Res. 5, 27.

Angstadt, A.Y., Thayanithy, V., Subramanian, S., Modiano, J.F. and Breen, M. 2012. A genome-wide approach to comparative oncology: high-resolution oligonucleotide aCGH of canine and human osteosarcoma pinpoints shared microaberrations. Cancer Genet. 205, 572-587.

Arrowsmith, J. 2011. Trial watch: phase III and submission failures: 2007-2010. Nat. Rev. Drug Discov.10, 87.

Balkwill, F., Charles, K.A. and Mantovani, A. 2005. Smoldering and Polarized Inflammation in the Initiation and Promotion of Malignant Disease. Cancer Cell. 3, 211-217.

Bernstein, L. 2002. Epidemiology of endocrine-related risk factors for breast cancer. J. Mammary Gland Biol. Neoplasia. 7, 3-15.

Block, G.E., Jensen, E.V. and Polley, T.Z. 1975. The prediction of hormonal dependency of mammary cancer. Ann. Surg. 182, 342-352.

Bonnett, B.N. and Egenvall, A. 2010. Age patterns of disease and death in insured Swedish dogs, cats and horses. J. Comp. Pathol. 142, 33-38.

Breen, M. and Modiano, J.F. 2008. Evolutionarily conserved cytogenetic changes in haematological malignancies of dogs and humans-man and his best friend share more than companionship. Chromosome Res. 16, 145-154.

Caserto, B.G. 2013. A comparative review of canine and human rhabdomyosarcoma with emphasis on classification and pathogenesis. Vet. Pathol. 50, 806-826.

Cekanova, M., Uddin, M.J., Bartges, J.W., Callens, A., Legendre, A.M., Rathore, K., Wright, L., Carter, A. and Marnett, L.J. 2013. Molecular imaging of cyclooxygenase-2 in canine transitional cell carcinomas in vitro and in vivo. Cancer Prev. Res. (Phila). 6, 466-476.

Chang, J. and Elledge, R.M. 2001.Clinical management of women with genomic BRCA1 and BRCA2 mutations. Breast Cancer Res. Treat. 69, 101-113.

Chen, C.H. and Chen, R.J. 2011. Prevalence of telomerase activity in human cancer. J. Formos. Med. Assoc. 110, 275-289.

Chesler, E.J., Wilson, S.G., Lariviere, W.R., Rodriguez-Zas, S.L. and Mogil, J.S. 2002. 
Identification and ranking of genetic and laboratory environment factors influencing a behavioural trait, thermal nociception, via computational analysis of a large data archive. Neurosci. Biobehav. Rev. 26, 907-923.

Chun, R., Knapp, D.W., Widmer, W.R., DeNicola, D.B., Glickman, N.W., Kuczek, T., Degortari, A. and Han, C.M. 1997. Phase II clinical trial of carboplatin in canine transitional cell carcinoma of the urinary bladder. J. Vet. Intern. Med. 11, 279283.

Cohen, D., Reif, J.S., Brodey, R.S. and Keiser, H. 1974. Epidemiological analysis of the most prevalent sites and types of canine neoplasia observed in a veterinary hospital. Cancer Res. 34, 2859-2868.

Cook, N., Jodrell, D.I. and Tuveson, D.A. 2012. Predictive in vivo animal models and translation to clinical trials. Drug Discov. Today. 17, 253-260.

Cummings, B.J., Head, E., Ruehl, W., Milgram, N.W. and Cotman, C.W. 1996. The canine as an animal model of human ageing and dementia. Neurobiol. Aging. 17, 259-268.

Davis, B.W. and Ostrander, E.A. 2014. Domestic Dogs and Cancer Research: A Breed-Based Genomics Approach. ILAR J. 55, 59-68.

Donnay, I., Rauis, J., Devleeschouwer, N., WoutersBallman, P., Leclercq, G. and Verstegen, J. 1995. Comparison of estrogen and progesterone receptor expression in normal and tumour mammary tissues from dogs. Am. J. Vet. Res. 56, 1188-1194.

Eissa, S., Motawi, T., Badr, S., Zaghlool, A. and Maher, A. 2013. Evaluation of urinary human telomerase reverse transcriptase mRNA and scatter factor protein as urine markers for diagnosis of bladder cancer. Clin. Lab. 59, 317-323.

Fowles, J.S., Dailey, D.D., Gustafson, D.L., Thamm, D.H. and Duval, D.L. 2017. The Flint Animal Cancer Center (FACC) Canine Tumour Cell Line Panel: a resource for veterinary drug discovery, comparative oncology and translational medicine. Vet. Comp. Oncol. 15, 481-492.

Gardner, H.L., Fenger, J.M. and London, C.A. 2016. Dogs as a Model for Cancer. Annu. Rev. Anim. Biosci. 4, 199-222.

Gershwin, L.J. 2007. Veterinary autoimmunity: autoimmune diseases in domestic animals. Ann. N. Y. Acad. Sci. 1109, 109-116.

Gillette, S.M., Dewhirst, M.W., Gillette, E.L., Thrall, D.E., Page, R.L, Powers, B.E., Withrow, S.J., Rosner, G., Wong, C. and Sim, D.A. 1992. Response of canine soft tissue sarcomas to radiation or radiation plus hyperthermia: a randomized phase II study. Int. J. Hyperthermia 8, 309-320.

Gondo, Y., Fukumura, R., Murata, T. and Makino, S. 2009. Next-generation gene targeting in the mouse for functional genomics. BMB Rep. 42, 315-323.
Gordon, I., Paoloni, M., Mazcko, C. and Khanna, C. 2009. The Comparative Oncology Trials Consortium: using spontaneously occurring cancers in dogs to inform the cancer drug development pathway. PLoS Med. 6, e1000161.

Goswami, S., Sahai, E., Wyckoff, J.B., Cammer, M., Cox, D., Pixley, F.J., Stanley, E.R., Segall, J.E. and Condeelis, J.S. 2005. Macrophages Promote the Invasion of Breast Carcinoma Cells via a Colony Stimulating Factor-1/Epidermal Growth Factor Paracrine Loop. Cancer Res. 65, 5278-5283.

Hahn, K.A., Bravo, L., Adams, W.H. and Frazier, D.L. 1994. Naturally Occurring Tumors in Dogs as Comparative Models for Cancer Therapy Research. In Vivo 8, 133-143.

Hansen, K. and Khanna, C. 2004. Spontaneous and genetically engineered animal models; use in preclinical cancer drug development. Eur. J. Cancer 40, 858-880.

Higuchi, T., Burcham, G.N., Childress, M.O., Rohleder, J.J., Bonney, P.L., Ramos-Vara, J.A. and Knapp, D.W. 2013 Characterization and treatment of transitional cell carcinoma of the abdominal wall in dogs: 24 cases (1985-2010). J. Am. Vet. Med. Assoc. 242, 499-506.

Hovey, R.C., McFadden, T.B. and Akers, R.M. 1999. Regulation of Mammary Gland Growth and Morphogenesis by the Mammary Fat Pad: A Species Comparison. J. Mammary Gland Biol. Neoplasia 4, 53-68.

Jemal, A., Bray, F., Center, M.M., Ferlay, J., Ward, E. and Forman, D. 2011. Cancer statistics, 2011. CA. Cancer J. Clin. 61, 69-90.

Karlsson, E.K. and Lindblad-Toh, K. 2008. Leader of the pack: gene mapping in dogs and other model organisms. Nat. Rev. Genet. 9, 713-725.

Khanna, C., Lindblad-Toh, K., Vail, D., London, C., Bergman, P., Barber, L., Breen, M., Kitchell, B., McNeil, E., Modiano, J.F., Modiano, J.F., Niemi, S., Comstock, K.E., Ostrander, E., Westmoreland, S. and Withrow, S. 2006. The dog as a cancer model. Nat. Biotechnol. 24, 1065-1066.

Kim, K., Chie, E.K., Han, W., Noh, D.Y., Park, I.A., Oh, D.Y., Im, S.A., Kim, T.Y., Bang, Y.J and Ha, S.W. 2010. Prognostic value of p53 and bcl2 expression in patients treated with breast conservative therapy. J. Korean Med. Sci. 25, 235239.

Kim, N.W., Piatyszek, M.A., Prowse, K.R., Harley, C.B., West, M.D., Ho, P.L., Coviello, G.M., Wright, W.E., Weinrich, S.L. and Shay, J.W. 1994. Specific association of human telomerase activity with immortal cells and cancer. Science. 266, 20112015.

Knapp, D.W., Glickman, N.W., Denicola, D.B., Bonney, P.L., Lin, T.L. and Glickman, L.T. 2000. 
Naturally-occurring canine transitional cell carcinoma of the urinary bladder: A relevant model of human invasive bladder cancer. Urol. Oncol. 5, 47-59.

Knapp, D.W., Richardson, R.C., Bottoms, G.D., Teclaw, R. and Chan, T.C. 1992. Phase I trial of piroxicam in 62 dogs bearing naturally occurring tumours. Cancer Chemother. Pharmacol. 29, 214218.

Knapp, D.W., Ramos-Vara, J.A., Moore, G.E., Dhawan, D., Bonney, P.L. and Young, K.E. 2014. Urinary bladder cancer in dogs, a naturally occurring model for cancer biology and drug development. ILAR J. 55, 100-118.

Krikelis, D. and Judson, I. 2010. Role of chemotherapy in the management of soft tissue sarcomas. Expert. Rev. Anticancer Ther. 10, 249-260.

LaRue, S.M., Withrow, S.J., Powers, B.E., Wrigley, R.H., Gillette, E.L., Schwarz, P.D., Straw, R.C. and Richter, S.L. 1989. Limb-sparing treatment for osteosarcoma in dogs. J. Am. Vet. Med. Assoc. 195, 1734-1744.

LeBlanc, A.K., Breen, M., Choyke, P., Dewhirst, M., Fan, T.M., Gustafson, D.L., Helman, L.J., Kastan, M.B., Knapp, D.W., Levin, W.J., London, C., Mason, N., Mazcko, C., Olson, P.N., Page, R., Teicher, B.A., Thamm, D.H., Trent, J.M., Vail, D.M. and Khanna, C. 2016. Perspectives from man's best friend: National Academy of Medicine's Workshop on Comparative Oncology. Sci. Transl. Med. 8, 324ps5.

Ledford, H. 2011. Translational research: 4 ways to fix the clinical trial. Nature. 477, 526-528.

Lee, C.H., Kim, W.H., Lim, J.H., Kang, M.S., Kim, D.Y. and Kweon, O.K. 2004. Mutation and overexpression of p53 as a prognostic factor in canine mammary tumours. J. Vet. Sci. 5, 63-69.

Lilienfeld, A.M. 1963. The epidemiology of breast cancer. Cancer Res. 23, 1503-1513.

Lindblad-Toh, K., Wade, C.M., Mikkelsen, T.S., Karlsson, E.K., Jaffe, D.B., Kamal, M., Clamp, M., Chang, J.L., Kulbokas, E.J., Zody, M.C., Mauceli, E., Xie, X., Breen, M., Wayne, R.K., Ostrander, E.A., Ponting, C.P., Galibert, F., Smith, D.R., DeJong, P.J., Kirkness, E., Alvarez, P., Biagi, T., Brockman, W., Butler, J., Chin, C.W., Cook, A., Cuff, J., Daly, M.J., DeCaprio, D., Gnerre, S., Grabherr, M., Kellis, M., Kleber, M., Bardeleben, C., Goodstadt, L., Heger, A., Hitte, C., Kim, L., Koepfli, K.P., Parker, H.G., Pollinger, J.P., Searle, S.M., Sutter, N.B., Thomas, R., Webber, C., Baldwin, J., Abebe, A., Abouelleil, A., Aftuck, L., Ait-Zahra, M., Aldredge, T., Allen, N., An, P., Anderson, S., Antoine, C., Arachchi, H., Aslam, A., Ayotte, L., Bachantsang, P., Barry, A., Bayul, T., Benamara, M., Berlin, A., Bessette, D., Blitshteyn,
B., Bloom, T., Blye, J., Boguslavskiy, L., Bonnet, C., Boukhgalter, B., Brown, A., Cahill, P., Calixte, N., Camarata, J., Cheshatsang, Y., Chu, J., Citroen, M., Collymore, A., Cooke, P., Dawoe, T., Daza, R., Decktor, K., DeGray, S., Dhargay, N., Dooley, K., Dooley, K., Dorje, P., Dorjee, K., Dorris, L., Duffey, N., Dupes, A., Egbiremolen, O., Elong, R., Falk, J., Farina, A., Faro, S., Ferguson, D., Ferreira, P., Fisher, S., FitzGerald, M., Foley, K., Foley, C., Franke, A., Friedrich, D., Gage, D., Garber, M., Gearin, G., Giannoukos, G., Goode, T., Goyette, A., Graham, J., Grandbois, E., Gyaltsen, K., Hafez, N., Hagopian, D., Hagos, B., Hall, J., Healy, C., Hegarty, R., Honan, T., Horn, A., Houde, N., Hughes, L., Hunnicutt, L., Husby, M., Jester, B., Jones, C., Kamat, A., Kanga, B., Kells, C., Khazanovich, D., Kieu, A.C., Kisner, P., Kumar, M., Lance, K., Landers, T., Lara, M., Lee, W., Leger, J.P., Lennon, N., Leuper, L., LeVine, S., Liu, J., Liu, X., Lokyitsang, Y., Lokyitsang, T., Lui, A., Macdonald, J., Major, J., Marabella, R., Maru, K., Matthews, C., McDonough, S., Mehta, T., Meldrim, J., Melnikov, A., Meneus, L., Mihalev, A., Mihova, T., Miller, K., Mittelman, R., Mlenga, V., Mulrain, L., Munson, G., Navidi, A., Naylor, J., Nguyen, T., Nguyen, N., Nguyen, C., Nguyen, T., Nicol, R., Norbu, N., Norbu, C., Novod, N., Nyima, T., Olandt, P., O'Neill, B., O'Neill, K., Osman, S., Oyono, L., Patti, C., Perrin, D., Phunkhang, P., Pierre, F., Priest, M., Rachupka, A., Raghuraman, S., Rameau, R., Ray, V., Raymond, C., Rege, F., Rise, C., Rogers, J., Rogov, P., Sahalie, J., Settipalli, S., Sharpe, T., Shea, T., Sheehan, M., Sherpa, N., Shi, J., Shih, D., Sloan, J., Smith, C., Sparrow, T., Stalker, J., Stange-Thomann, N., Stavropoulos, .S, Stone, C., Stone, S., Sykes, S., Tchuinga, P., Tenzing, P., Tesfaye, S., Thoulutsang, D., Thoulutsang, Y., Topham, K., Topping, I., Tsamla, T., Vassiliev, H., Venkataraman, V., Vo, A., Wangchuk, T., Wangdi, T., Weiand, M., Wilkinson, J., Wilson, A., Yadav, S., Yang, S., Yang, X., Young, G., Yu, Q., Zainoun, J., Zembek, L., Zimmer, A. and Lander, E.S. 2005. Genome sequence, comparative analysis and haplotype structure of the domestic dog. Nature 438, 803-819.

Liu, D., Xiong, H., Ellis, A.E., Northrup, N.C., Rodriguez, CO, Jr., O'Regan, R.M., Dalton, S. and Zhao, S. 2014. Molecular homology and difference between spontaneous canine mammary cancer and human breast cancer. Cancer Res. 74, 5045-5056.

London, C.A., Hannah, A.L., Zadovoskaya, R., Chien, M.B., Kollias-Baker, C., Rosenberg, M., Downing, S., Post, G., Boucher, J., Shenoy, N., Mendel, D.B., McMahon, G. and Cherrington, J.M. 2003. Phase I dose escalating study of SU11654, a small molecule receptor tyrosine kinase inhibitor, in dogs with 
spontaneous malignancies. Clin. Cancer Res. 9, 2755-2768.

Loscher, W., Schwartz-Porsche, D., Frey, H.H. and Schmidt, D. 1985.Evaluation of epileptic dogs as an animal model of human epilepsy. Arzneimittelforschung 35, 82-87.

MacEwen, E.G., Patnaik, A.K., Harvey, H.J., Panko, W.B. 1982. Estrogen receptors in canine mammary tumours. Cancer Res. 42, 2255-2259.

MacEwen, E.G., Rosenthal, R.C., Fox, L.E., Loar, A.S. and Kurzman, I.D. 1992. Evaluation of Lasparaginase: polyethylene glycol conjugate versus native L-asparaginase combined with chemotherapy. A randomized double-blind study in canine lymphoma. J. Vet. Intern. Med. 6, 230-234.

MacLeod, R.A., Dirks, W.G., Matsuo, Y., Kaufmann, M., Milch, H. and Drexler, H.G. 1999. Widespread intraspecies cross-contamination of human tumour cell lines arising at source. Int. J. Cancer 83, 555563.

Mak, I.W., Evaniew, N. and Ghert, M. 2014. Lost in translation: animal models and clinical trials in cancer treatment. Am. J. Transl. Res. 6, 114-118.

Marchetti, S. and Schellens, J.H. 2007. The impact of FDA and EMEA guidelines on drug development in relation to Phase 0 trials. Br. J. Cancer 97, 577- 581.

Masters, J.R. 2002. HeLa cells 50 years on: the good, the bad and the ugly. Nat. Rev. Cancer 2, 315-319.

McCleary-Wheeler, A.L., Williams, L.E., Hess, P.R. and Suter, S.E. 2010. Evaluation of an in vitro telomeric repeat amplification protocol assay to detect telomerase activity in canine urine. Am. J. Vet. Res. 71, 1468-1474.

McEwen, E.G. 1990. Spontaneous Tumors in Dogs and Cats: Models for the Study OF Cancer Biology and Treatment. Cancer Metastasis Rev. 9, 125-136.

Merlo, D.F., Rossi, L., Pellegrino, C., Ceppi, M., Cardellino, U., Capurro, C., Ratto, A., Sambucco, P.L., Sestito, V., Tanara, G. and Bocchini, V. 2008. Cancer incidence in pet dogs: Findings of the Animal Tumor Registry of Genoa, Italy. J. Vet. Intern. Med. 22, 976-984.

Meuten, D.J. and Meuten, T.L.K. 2014. Tumors of the urinary system. In: Meuten DJ. Tumors in Domestic Animals, $5^{\text {th }}$ ed. Hoboken NJ: Wiley.

Mirabello, L., Troisi, R.J. and Savage, S.A. 2009. Osteosarcoma incidence and survival rates from 1973 to 2004: Data from the Surveillance, Epidemiology, and End Results Program. Cancer 115, 1531-1543.

Mohammed, S.I., Knapp, D.W., Bostwick, D.G., Foster, R.S., Khan, K.N., Masferrer, J.L., Woerner, B.M., Snyder, P.W., Koki, A.T. 1999. Expression of cyclooxygenase-2 (COX-2) in human invasive transitional cell carcinoma (TCC) of the urinary bladder. Cancer Res. 59, 5647-5650.
Overall, K.L. 2000. Natural animal models of human psychiatric conditions: assessment of mechanism and validity. Prog. Neuropsychopharmacol. Biol. Psychiatry 24, 727-776.

Paigen, K. 1995. A miracle enough: the power of mice. Nat. Med. 1, 215-220.

Paoloni, M., Davis, S., Lana, S., Withrow, S., Sangiorgi, L., Picci, P., Hewitt, S., Triche, T., Meltzer, P. and Khanna, C. 2009. Canine tumour cross-species genomics uncovers targets linked to osteosarcoma progression. BMC Genomics 10, 625. doi: 10.1186/1471-2164-10-625.

Paoloni, M. and Khanna, C. 2008. Translation of new cancer treatments from pet dogs to humans. Nat. Rev. Cancer 8, 147-156.

Paoloni, M.C., Mazcko, C., Fox, E., Fan, T., Lana, S., Kisseberth, W., Vail, D.M., Nuckolls, K., Osborne, T., Yalkowsy, S., Gustafson, D., Yu, Y., Cao, L. and Khanna C. 2010. Rapamycin pharmacokinetic and pharmacodynamic relationships in osteosarcoma: a comparative oncology study in dogs. PLoS One. 5, e11013. doi: 10.1371/journal.pone.0011013.

Park, J.C. and Hahn, N.M. 2014. Bladder cancer: a disease ripe for major advances. Clin. Adv. Hematol. Oncol. 12, 838-845.

Parker, H.G., Meurs, K.M. and Ostrander, EA. 2006. Finding cardiovascular disease genes in the dog. J. Vet. Cardiol. 8, 115-127.

Parodi, A.L., Misdorp, W., Mialot, J.P., Mialot, M., Hart, A.A., Hurtrel, M. and Salomon, J.C. 1983. Intratumoral BCG and Corynebacteriumparvum therapy of canine mammary tumours before radical mastectomy. Cancer Immunol. Immunother. 15, 172-177.

Patronek, G.J., Waters, D.J. and Glickman, L.T. 1997. Comparative longevity of pet dogs and humans: implications for gerontology research. J. Gerontol. A. Biol. Sci. Med. Sci. 52, 171-178.

Perel, P., Roberts, I., Sena, E., Wheble, P., Briscoe, C., Sandercock, P., Macleod, M., Mignini, L.E., Jayaram, P. and Khan, K.S. 2007. Comparison of treatment effects between animal experiments and clinical trials: systematic review. BMJ. 334, 197.

Priester, W.A. 1977. Multiple primary tumours in domestic animals: a preliminary view with particular emphasis on tumours in dogs. Cancer 40, 1845-1848.

Prowse, K.R. and Greider, C.W. 1995. Developmental and tissue-specific regulation of mouse telomerase and telomere length. Proc. Natl. Acad. Sci. USA. 92, 4818-4822.

Ramsey, S.A., Xu, T., Goodall, C., Rhodes, A.C., Kashyap, A., He and J., Bracha, S. 2017. Cross-Species Analysis of the Canine and Human Bladder Cancer Transcriptome and Exome. Genes Chromosomes Cancer. 56, 328-343. 
Ru, G., Terracini, B. and Glickman, L.T. 1998. Host related risk factors for canine osteosarcoma. Vet. J. 156, 31-39.

Rusk, A., Cozzi, E., Stebbins, M., Vail, D., Graham, J., Valli, V., Henkin, J., Sharpee, R. and Khanna, C. 2006. Cooperative activity of cytotoxic chemotherapy with antiangiogenic thrombospondin-I peptides, ABT-526 in pet dogs with relapsed lymphoma. Clin. Cancer Res. 12, 7456-7464.

Rutteman, G.R., Misdorp, W., Blankenstein, M.A. and van den Brom, W.E. 1988. Oestrogen (ER) and progestin receptors (PR) in mammary tissue of the female dog: different receptor profile in nonmalignant and malignant states. Br. J. Cancer. 58, 594-599.

Sahora, A.I., Rusk, A.W., Henkin, J., McKeegan, E.M., Shi, Y. and Khanna, C. 2012. Prospective study of thrombospondin-1 mimetic peptides, ABT-510 and ABT-898, in dogs with soft tissue sarcoma. J. Vet. Intern. Med. 26, 1169-1176.

Schiffman, J.D. and Breen, M. 2015. Comparative oncology: what dogs and other species can teach us about humans with cancer. Philos. Trans. R. Soc. Lond. B. Biol. Sci. 370: 20140231. doi: 10.1098/rstb.2014.0231.

Schuh, J.C. 2004. Trials, tribulations, and trends in tumour modeling in mice. Toxicol. Pathol. 32, 5366.

Schwertfeger, K.L., Rosen, J.M. and Cohen, D.A. 2006. Mammary Gland Macrophages: Pleiotropic Functions in Mammary Development. J. Mammary Gland Biol. Neoplasia. 11, 229-238.

Selvarajah, G.T., Kirpensteijn, J., van Wolferen, M.E., Rao, N.A., Fieten and H., Mol, J.A. 2009. Gene expression profiling of canine osteosarcoma reveals genes associated with short and long survival times. Mol. Cancer. 8, 72.

Sena, E.S., vander Worp, H.B., Bath, P.M., Howells, D.W. and Macleod, M.R. 2010. Publication bias in reports of animal stroke studies leads to major overstatement of efficacy. PLoS Biol. 8: e1000344.

Seok, J., Warren, H.S., Cuenca, A.G., Mindrinos, M.N., Baker, H.V., Xu, W., Richards, D.R., McDonaldSmith, G.P., Gao, H., Hennessy, L., Finnerty, C.C., López, C.M., Honari, S., Moore, E.E., Minei, J.P., Cuschieri, J., Bankey, P.E., Johnson, J.L., Sperry, J., Nathens, A.B., Billiar, T.R., West, M.A., Jeschke, M.G., Klein, M.B., Gamelli, R.L., Gibran, N.S., Brownstein, B.H., Miller-Graziano, C., Calvano, S.E., Mason, P.H., Cobb, J.P., Rahme, L.G., Lowry, S.F., Maier, R.V., Moldawer, L.L., Herndon, D.N., Davis, R.W., Xiao, W. and Tompkins, R.G. 2013. Inflammation and Host Response to Injury, Large Scale Collaborative Research Program. Genomic responses in mouse models poorly mimic human inflammatory diseases. Proc. Nat.1 Acad. Sci. USA.110, 35073512 .

Shirahama, T. 2000. Cyclooxygenase-2 expression is up-regulated in transitional cell carcinoma and its preneoplastic lesions in the human urinary bladder. Clin. Cancer. Res. 6, 2424-2430.

Simon, R. 2008. Lost in translation: problems and pitfalls in translating laboratory observations to clinical utility. Eur. J. Cancer. 44, 2707-2713.

Singer, J., Fazekas, J., Wang, W., Weichselbaumer, M., Matz, M., Mader, A., Steinfellner, W., Meitz, S., Mechtcheriakova, D., Sobanov, Y., Willmann, M., Stockner, T., Spillner, E., Kunert, R. and Jensen-Jarolim, E. 2014. Generation of a Canine Anti-EGFR (ErbB-1) Antibody for Passive Immunotherapy in Dog Cancer Patients. Mol. Cancer. Ther.13, 1777-1790.

Smith, D., Broadhead, C., Descotes, G., Fosse, R., Hack, R., Krauser, K., Pfister, R., Phillips, B., Rabemampianina, Y., Sanders, J., Sparrow, S., Stephan-Gueldner, M., Jacobsen, S.D. 2002. Preclinical Safety Evaluation Using Nonrodent Species: An Industry/Welfare Project to Minimize Dog Use. ILAR J. 43, 39-42.

Sorenmo, K. 2003. Canine mammary gland tumours. Vet. Clin. North. Am. Small Anim. Pract. 33, 573596.

Starkey, M.P., Scase, T.J., Mellersh, C.S. and Murphy, S. 2005. Dogs really are man's best friend--canine genomics has applications in veterinary and human medicine! Brief Funct. Genomic Proteomic. 4, 112128.

Stratus, A.C., Cook, J.E. and Smith, I.E. 1976. Squamous Carcinoma in dogs. J. Am. Vet. Med. Assoc. 168, 425-427.

Strauch, K., Fimmers, R., Baur, M.P. and Wienker, T.F. 2003. How to model a complex trait. 1. General considerations and suggestions. Hum. Hered. 55, 202-210.

Surget, S., Khoury, M.P. and Bourdon, J.C. 2013. Uncovering the role of p53 splice variants in human malignancy: a clinical perspective. Onco. Targets Ther. 7, 57-68.

Teicher, B.A. 2009. In vivo/ex vivo and in situ assays used in cancer research: a brief review. Toxicol. Pathol. 37,114-122.

Teske, E., Rutteman, G.R., vdIngh, T.S., van Noort, R. and Misdorp, W. 1998. Liposome-encapsulated muramyl tripeptide phosphatidylethanolamine (LMTP-PE): a randomized clinical trial in dogs with mammary carcinoma. Anticancer Res. 18, 10151019.

Vail, D.M. and MacEwen, E.G. 2000. Spontaneously occurring tumors of companion animals as models for human cancer. Cancer. Invest. 18, 781-792. 
Vail, D.M., Kurzman, I.D., Glawe, P.C., O’Brien, M.G., Chun, R., Garrett, L.D., Obradovich, J.E., Fred, R.M., Khanna, C., Colbern, G.T. and Working, P.K. 2002. STEALTH liposomeencapsulated cisplatin (SPI-77) versus carboplatin as adjuvant therapy for spontaneously arising osteosarcoma (OSA) in the dog: a randomized multicenter clinical trial. Cancer Chemother.
Pharmacol. 50, 131-136.

Vezzali, E., Parodi, A.L., Marcato, P.S. and Bettini, G. 2010. Histopathologic classification of 171 cases of canine and feline non-Hodgkin lymphoma according to the WHO. Vet. Comp. Oncol.8, 38-49.

Withrow, S.J. and Wilkins, R.M. 2010. Cross talk from pets to people: translational osteosarcoma treatments. ILAR J. 51, 208-213. 